\title{
Blocking Both E-Selectin and P-Selectin Inhibits Neutrophil Recruitment into the Murine Testis after Ischemia-Reperfusion-Induced Injury
}

\author{
M. CELEBI ${ }^{1,2}$, A.G.A. PAUL ${ }^{3}$ \\ ${ }^{1}$ Cardiovascular Division, University of Virginia School of Medicine, Charlottesville, VA, USA \\ ${ }^{2}$ Department of Reproduction, Faculty of Veterinary Medicine, University of Ondokuz Mayis, \\ Samsun, Turkey \\ ${ }^{3}$ Department of Pathology, University of Virginia School of Medicine, Charlottesville, VA, USA \\ Received September 28, 2007 \\ Accepted June 11, 2008
}

\begin{abstract}
Celebı M., A.G.A. Paul: Blocking Both E-Selectin and P-Selectin Inhibits Neutrophil Recruitment into the Murine Testis after Ischemia-Reperfusion-Induced Injury. Acta Vet. Brno 76, 2008: 321-326.

Ischemia-reperfusion (IR) injury of the testis results in germ cell specific apoptosis, a process in which neutrophil recruitment to the testes plays a critical role. Adhesion molecules, in particular $\mathrm{E}$ - and P-selectins, play a critical role in this recruitment. The present study sought to characterize the inhibitory effect of function-blocking monoclonal anti-mouse E- and P-selectin antibodies on the migration of neutrophils into the IR-induced testis of the mouse. Mice were subjected to a 2 $\mathrm{hr}$ period of testicular torsion (ischemia) followed by detorsion (reperfusion). Ten minutes after the onset of reperfusion mice received either a mixture of $200 \mu \mathrm{g}$ function-blocking monoclonal E-selectin and P-selectin antibody (FBMAb group; $100 \mu \mathrm{g}$; each) intravenously or $200 \mu \mathrm{g}$ of isotype-matched control-antibody (IMCAb group). Separate groups of mice underwent shamoperation (SO group) or received $500 \mathrm{ng}$ of TNF $\alpha$ (IF group) to induce inflammation. Mice were sacrificed $24 \mathrm{~h}$ after reperfusion and testicular interstitial cells were isolated and analyzed for the presence of neutrophils by means of flow cytometry.

The mixture of function-blocking monoclonal E- and P-selectin antibody (FBMAb) decreased neutrophil recruitment to the IR-induced testis significantly (FBMAb group as compared to the IMCAb group $20.2 \pm 2.8$ vs. $51.9 \pm 4.0 \% \mathrm{Gr}-1+\mathrm{CD} 11 \mathrm{~b}+$ of total leukocytes; $p=0.0002)$. Therefore, blocking both E- and P-selectin may be therapeutically beneficial to protect postischemic testis.
\end{abstract}

Selectin, neutrophil, testis, murine, torsion, antibody

In the clinical setting ischemia-reperfusion (IR)-induced testicular injury results from torsion of the spermatic cord which renders the testis ischemic (Lysiak et al. 2003). IR-induced testicular injury results in germ cell specific apoptosis and can lead to the permanent loss of spermatogenesis in animal models (Lysiak et al. 2000; Turner et al. 1997). Studies in animal models have demonstrated that neutrophil recruitment to the testes plays a critical role in the germ cell apoptosis induced after IR-induced testicular injury. E-selectin, expressed on the testicular endothelial cells, appears to be the key cell adhesion molecule responsible for mediating neutrophil recruitment (Lysiak et al. 2001, Sukhotnik et al. 2007). The selectin family of adhesion molecules, P- E- and L-selectins, mediate the initial attachment of leukocytes to venular endothelial cells before their firm adhesion and diapedesis at sites of tissue injury and inflammation. L-selectin is expressed on all leukocytes, P-selectin is expressed on platelets and endothelial cells, and E-selectin is found exclusively on endothelial cells (Tedder et al. 1995). P-selectin participates in leukocyte capture and rolling on the venular endothelial surface upon inflammatory stimuli and is transported to the endothelial cell surface within minutes of injury (Ley et al. 1995), and can persist in a synthesis-dependent manner for hours after IR-induced injury (Chukwuemeka et al. 2005). E-selectin participates to tether and allows for the slow rolling of neutrophils to endothelial cells (Kunkel and Ley 1996) and E-selectin

Address for correspondence:

Dr. Muzaffer Celebi

Faculty of Veterinary Medicine

University of Ondokuz Mayis

55139 Samsun, Turkey
Phone: $+90-362-3121919$ ext. 3169

Fax: +90-362-4579622

E-mail: muzaffercelebi2002@yahoo.com

Alternative e-mail:m.celebi@omu.tr

http://www.vfu.cz/acta-vet/actavet.htm 
expression in the testicular vascular endothelium is up-regulated following IR-induced injury or after treatment with tumor necrosis factor $\alpha$ (Weller et al. 1992) or interleukin $1 \beta$ (Keelan et al. 1994). Previous studies have demonstrated that blocking E-and P-selectins in models of IR-induced tissue injuries (Singbartl and Ley 2000; Singbartl et al. 2000) and inflammation (Homeister et al. 1998) reduces neutrophil migration to the tissues and protect from IR-induced organ failures. Therefore, blockade of E- and P-selectin function may have therapeutic benefit. The effect of blocking E- and P-selectin by means of antibody (Ab) blockade has not been investigated in IR-induced testicular injury.

This study was aimed to determine whether functional-blocking monoclonal antibodies against mouse E-selectin and P-selectin could inhibit the recruitment of neutrophils into the murine testis subjected to IR.

\section{Materials and Methods}

Experimental Testicular Torsion

All experiments were conducted in a humane manner and approved by the Virginia University Institutional Animal Care and Use Committee. Adult male C57BL/6 mice were anaesthetized with an intraperitoneal injection of ketamine (60 mg/kg; Ford Dodge, Iowa; Ketaset) and xylazine (5mg/kg; Burns Vet supply, Westbury, NY). Mice were subjected to unilateral testicular torsion as described by Lysiak et al. (2001). The testis was rotated $720^{\circ}$ for $2 \mathrm{~h}$ (ischemia), during that time it remained in the abdomen with a closed incision. After $2 \mathrm{~h}$ the incision was reopened, the testis was counter rotated to the natural position (reperfusion) and reinserted into the scrotum, and the incision was closed. Ten minutes after reperfusion, mice received either a mixture of $200 \mu \mathrm{g}$ function-blocking monoclonal E-selectin and P-selectin antibody (FBMAb group, $\mathrm{n}=6 ; 100 \mu \mathrm{g}$ of each antibody) intravenously or $200 \mu \mathrm{g}$ of isotype-matched control-antibody (IMCAb group, $\mathrm{n}=6$; Sigma, I4131, IgG from rat serum). Function blocking monoclonal anti-mouse E-selectin antibody (clone 9A9) and P-selectin antibody (clone Rb40.34) were produced at the University of Virginia lymphocyte Culture Center (Charlottesville VA, described in reference Norton et al. (1993) and Bosse et al. (1994). Separate groups of mice underwent sham-operation (SO group, $\mathrm{n}=5$ ) or received $500 \mathrm{ng}$ of TNF $\alpha$ to induce inflammation (IF group, $\mathrm{n}=6$ ). Intratesticular injection of TNF $\alpha$ was performed as described by Lysiak et al. (2003). Mice were sacrificed $24 \mathrm{~h}$ after reperfusion and testis were removed for flow cytometry study to determine the neutrophil content.

Isolation of interstitial cells

Isolation of testicular cells was performed as described by Suescun et al. (2003) with minor modifications. For isolation of interstitial cells (both inflammatory cells and testis-resident cells as germ cells/Leydig cells) the testis was decapsulated and placed in $3 \mathrm{ml}$ of RPMI1640 (Dulbecco's) containing $100 \mathrm{U} / \mathrm{ml} \mathrm{Collagenase}$ Type 2 (Worthington Biochemical Corp.) and 0.1 M DnaseI (Sigma; type IV). This was subsequently incubated for $15 \mathrm{~min}$ in a $34{ }^{\circ} \mathrm{C}$ water bath while shaking. After incubation, $40 \mathrm{ml}$ of $0.1 \mathrm{M}$ EDTA in HBBS was added and non-interstitial contents (containing seminiferous tubules) were allowed to settle by incubation on ice for $3 \mathrm{~min}$. The supernatant (containing interstitial testicular cells) was collected and washed once in HBSS. Isolated interstitial cells were counted by trypan blue exclusion and further processed for flow cytometric analysis.

Flow cytometric analysis

Isolated testicular interstitial cells were resuspended in $50 \mu \mathrm{g} / \mathrm{ml} \mathrm{Fc-block} \mathrm{(anti-CD16/32;} \mathrm{clone} \mathrm{G412,} \mathrm{BD}$ Pharmingen) in PBS $+0.5 \% \mathrm{BSA}$ and incubated for $15 \mathrm{~min}$ at $4{ }^{\circ} \mathrm{C}$ in order to block Fc-receptor binding of antibodies used for staining of cells. Subsequently cells were transferred to a 96-wells round-bottomed plate. Surface staining for leukocyte-specific antigens and identification of neutrophils was then performed by using a combination of the following antibodies; Gr-1-PE (clone RB6-8C5; BDPharmingen), CD45-APC (clone 30-F11, BDPharmingen), CD11b-APCAlexaFluo750 (Clone M1/70; Ebioscience) and F4/80-biotin (clone BM8; Caltag Lab.). After $20 \mathrm{~min}$ incubation at $4{ }^{\circ} \mathrm{C}$, cells were washed twice with PBS $+0.5 \% \mathrm{BSA}$ and subsequently incubated with Streptavidine-FITC (BDPharmingen) for $20 \mathrm{~min}$ at $4{ }^{\circ} \mathrm{C}$. After three washes cells were resuspended in 100 $\mu \mathrm{PBS}+1 \% \mathrm{BSA}+0.1 \mathrm{M}$ EDTA plus $5 \mu \mathrm{l}$ of the viability dye 7-AAD (BDPharmingen). Samples were acquired on a FACScan upgraded with a blue laser by Cytek (Freemont, CA, USA) to allow five color-analysis. Data compensation and analysis was performed by using the Flowjo-software (Treestar).

Statistical analysis

Statistical analysis was performed using the non-parametric Mann-Whitney U-test with $p \leq 0.05$ considered statistically significant. All data are expressed as mean \pm standard error of the mean (SEM).

\section{Results and Discussion}

In order to identify neutrophils in the testis we used a specific combination of fluorchromeconjugated monoclonal antibodies that have been reported to properly identify neutrophils 

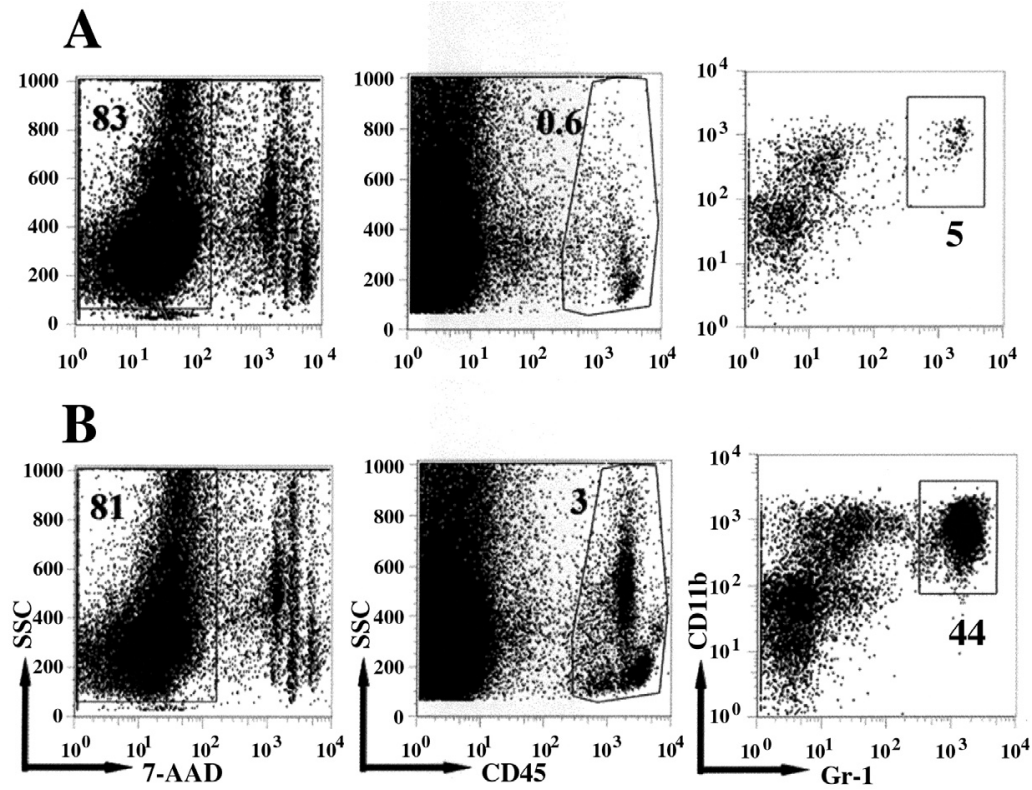

Fig. 1. Gating strategy to identify neutrophils in the isolated testicular cells of the different groups. Dot plots represent one representative mice in the sham-operated (SO) group (A) or IMCAb group (B). Dead cells were excluded by gating on the 7-AAD negative cells (live cells; left dot-plots) and leukocytes were subsequently identified by expression of CD45 (middle dot-plots). Neutrophils were identified in the gated leukocyte population as co-expressing CD11b and Gr-1 (left dot-plots) and were F4/80-negative (data not shown)

in the mouse (Lagasse et al. 1996). Fig. 1 shows the gating strategy used for identifying neutrophils in the testis of one representative mouse in either the SO group (A) or IMCAb group (B). First dead cells were excluded by use of 7-AAD staining (Fig. 1A and Fig. 1B; dot plots on the left) and subsequently leukocytes were gated on CD45 (Fig. 1A and Fig. 1B; dot plots in the middle). Neutrophils in the leukocyte population were then identified by coexpression of CD11b and Gr-1 (Fig. 1A and Fig. 1B; dot plots on the right) and were F4/80 negative (data not shown). The summary of the flow cytometric analysis is depicted in Fig. 2 and shows a significant reduction in the percentage of neutrophils present in the testicular cells isolated from the mice in the FBMAb group as compared to the IMCAb group (Fig. 2; $20.2 \pm$ 2.8 vs. $51.9 \pm 4.0 \% \mathrm{Gr}-1+\mathrm{CD} 11 \mathrm{~b}+$ of total leukocytes; $\mathrm{P}=0.0002)$. Deliberate induction of an inflammatory response by injecting $\mathrm{TNF} \alpha$ induced a significant increase in the percentage of neutrophils in the testicular cells of the IF group as compared to the SO group (Fig. 2; $59.9 \pm$ 8.8 vs. $6.5 \pm 1.6 \%$, respectively). This is consistent with the finding that E-selectin expression in the testicular vascular endothelium is up-regulated after treatment with tumor necrosis factor $\alpha$ (Weller et al. 1992) and that E-selectin appears to be the key cell adhesion molecule responsible for mediating neutrophil recruitment into the testis after IR-induced testicular injury (Lysiak et al. 2001, Sukhotnik et al. 2007) and would suggest that also during an inflammatory response in the testis E-selectin mediates neutrophil recruitment.

Germ cell-specific apoptosis occurs contemporaneously with an increase in neutrophil margination and diapedesis in the mouse (Lysiak et al. 2001) or rat (Turner et al. 1997). Neutrophil recruitment to the affected organs is one of the hallmarks of IR-induced injury (Singbartl and Ley 2000) and the precise role of each selectin (E-, P-, and L-) may vary depending on the particular inflammatory stimulus and species (Homeister et al. 1998). In this study our aim was to reduce neutrophil infiltration into the testis subjected to IR-induced 


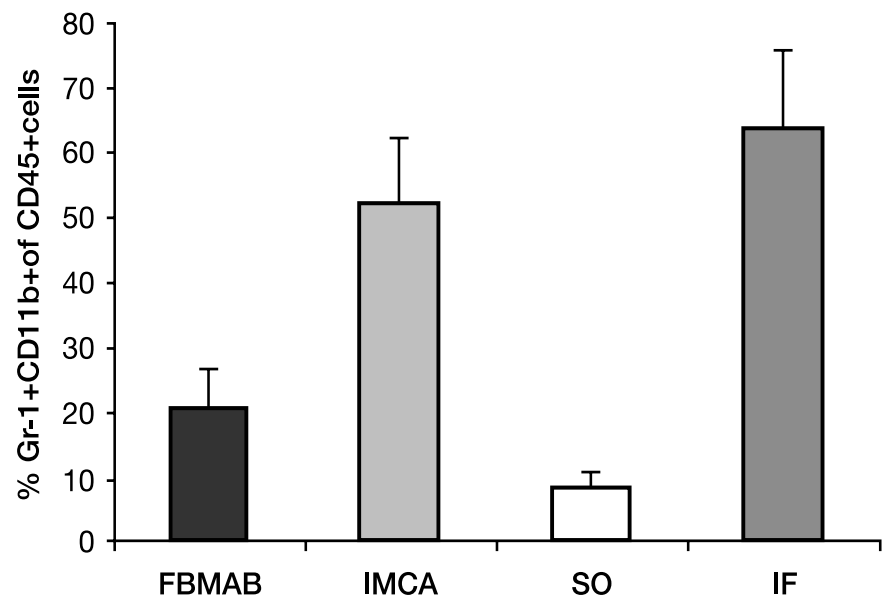

Fig. 2. The \% of neutrophils (Gr-1- and CD11b-positive and F4/80-negative) of leukocytes (CD45-positive cells) in live interstitial testicular cells isolated from mice that were sham-operated (SO) as compared to mice subjected to IR-induced testicular injury given isotype control (IMCAb) or a mixture of function-blocking monoclonal Eand P-selectin antibodies (FBMAb). The administration of FBMAb reduces the \% of neutrophils in the isolated interstitial cells significantly $(\mathrm{P}=0.0002)$. As a positive control mice were injected with TNF $\alpha$ (IF) to induce an inflammatory response.

injury with a mixture of function-blocking monoclonal E- and P-selectin antibodies. In this study, we show by flow cytometric analysis that neutrophil infiltration into the testis with IR-induced injury was reduced significantly, by $61 \%$, with the administration of FBMAb. Homeister et al. (1998) has shown that neutrophil accumulation was significantly reduced in mice deficient in both E- and P-selectin in acute dermal inflammation and he suggested that loss of both selectins was required to impair neutrophil accumulation. Blocking both E- and P-selectins decreased neutrophil recruitment into the kidney in IR-induced injury even after the onset of reperfusion in mice (Singbartl and Ley 2000; Singbartl et al. 2000). Lysiak et al. (2001) reported that E-selectin knockout mice and wild-type mice rendered neutropenic showed a significant decrease in neutrophil recruitment to the subtunical venules of the testis in IR-induced testicular injury. However no data existed until now regarding the active inhibition of neutrophil migration into the testis with IRinduced injury by means of Ab-blockade, which could be therapeutically applicable.

Our data are consistent with the results of other investigators who demonstrated that blockade of both E- and P-selectin reduces neutrophil migration into the tissues with IR-induced injury (Singbartl and Ley 2000; Singbartl et al. 2000) or inflamed tissues (Homeister et al. 1998).

In conclusion, these data demonstrate that blocking both E- and P-selectin, even after the onset of reperfusion, with function blocking monoclonal anti-mouse E- and P-selectin antibodies inhibits neutrophil recruitment into the testis subjected to IR-induced injury. Combined antibody therapy, inhibiting both P- and E-selectin, may be a promising strategy for protection against ischemia-reperfusion injury.

\section{Blokování E-selektinu i P-selektinu inhibuje prostup neutrofilů do myších varlat po ischemické reperfuzi}

Ischemická reperfuze (IR) varlat zpơsobuje apoptózu spermií, což je proces, př̀i kterém hraje hlavní roli prostup neutrofilů do tkáně varlat. Adhezní molekuly E- a P-selektiny mají 
pro prostup klíčový význam. Tato studie se snaží určit funkci selektivně blokujících monoklonárních anti-myších E-a P-selektinových protilátek na prostup neutrofilů do varlat myších samců, u kterých byla vyvolána IR. Myši podstoupily 2 hodinovou torzi varlat (ischémie) a následnou retorzí varlat došlo $\mathrm{k}$ reperfuzi (IR). Deset minut po nástupu reperfuze byla myším aplikována i.v. bud' směs $200 \mu$ g selektivně blokujících monoklonárních E- a P-selektinových protilátek (skupina FBMAb, $100 \mu \mathrm{g}$ pro toto) nebo $200 \mu \mathrm{g}$ kontrolních protilátek stejného izotypu (skupina IMCAb). Jednotlivé skupiny myší postoupily zdánlivou operaci (skupina SO) nebo jim bylo aplikováno 500 ng TNFa (skupina IF) k vyvolání zánětu. Myši byly utraceny 24 hodin po reperfuzi. Pomocí průtokové cytometrie byly izolovány a analyzovány intersticiální buňky varlat za účelem zjištění přítomnosti neutrofilů. Směs selektivně blokujících monoklonárních E- a P-selektinových protilátek (FBMAb) významně snížila prostup neutrofilů do varlat (skupina FBMAb ve srovnání se skupinou IMCAb $20,2 \pm 2,8$ vs. $51,9 \pm 4,0 \%$ Gr-1+CD11b+ celkových leukocytů; $p=0,0002)$. Blokování P- i E-selektinu tedy může být terapeuticky př́nosné při ochraně varlat po ischemii.

\section{Acknowledgments}

We thank Dr. Klaus Ley, Dr. Alexander L. Klibanov and Dr. Joshua J. Rychak for advice and Dr. Ley for providing the E- and P-selectin monoclonal antibodies. We thank Dr. Kenneth S. Tung for making available the antibodies used for flow cytometric analysis and usage of the flow cytometer.

\section{References}

BOSSE R, VESTWEBER D 1994: Only simultaneous blocking of the L- and P-selectin completely inhibits neutrophil migration into mouse peritoneum. Eur J Immunol 24: 3019-3024

CHUKWUEMEKA AO, BROWN A, VENN GE, CHAMBERS DJ 2005: Changes in P-selectin expression on cardiac microvessels in blood-perfused rat hearts subjected to ischemia reperfusion. Ann Thorac Surg 79: 204-211

HOMEISTER JW, ZHANG M, PAUL S, FRENETTE RO, HYNES DD, WAGNER JBL, LOWE, RORY MM 1998: Overlapping functions of E- and P-selectin in neutrophil recruitment during acute inflammation. Blood 92: $2345-2352$

KEELAN ET, LICENCE ST, PETERS AM, BINNS RM, HASKARD, DO 1994: Characterization of E-selectin expression in vivo with use of a radiolabeled monoclonal antibody. Am J Physiol 266: 278-290

KUNKEL EJ, LEY K 1996: Distinct phenotype of E-selectin-deficient mice. E-selectin is required for slow leukocyte rolling in vivo. Circ Res 79: 1196-1204

LAGASSE E, WEISSMAN E 1996: Flow cytometric identification of murine neutrophils and monocytes. J Immunol Methods 197: 139-150

LEY K, BULLARD DC, ARBONES ML, BOSSE R, VESTWEBER D, TEDDER TF, BEAUDET AL 1995: Sequential contribution of L- and P-selectin to leukocyte rolling in vivo. J Exp Med 181: 669-675

LYSİAK JJ, NGUYEN QA, KIRBY JL, TURNER TT 2003: Ischemia-reperfusion of the murine testis stimulates the expression of proinflammatory cytokines and activation of c-jun N-terminal kinase in a pathway to E-selectin expression. Biol Reprod 69: 202-210

LYSIAK JJ, TURNER SD, NGUYEN QA, SINGBARTL K, LEY K, TURNER TT 2001: Essential role of neutrophils in germ cell specific apoptosis following ischemia/reperfusion injury of the mouse testis. Biol Reprod 65: 718-725

LYSIAK JJ, NGUYEN QA, TURNER TT 2000: Fluctuations in rat testicular interstitial oxygen tensions are linked to testicular vasomotion: persistence after repair of torsion. Biol Reprod 63: 1383-1389

NORTON CR, RUMBERGER JM, BURNS DK, WOLITZKY BA 1993: Characterization of murine E-selectin expression in vitro using novel anti-mouse E-selectin monoclonal antibodies. Biochem Biophys Res Commun 195: $250-258$

SINGBARTL K, LEY K 2000: Protection from ischemia-reperfusion induced severe acute renal failure by blocking E-selectin. Crit Care Med 28: 2507-2514

SINGBARTL K, GREEN SA, LEY K 2000: Blocking P-selectin protects from ischemia/reperfusion-induced acute renal failure. Faseb J 14: 48-54.

SUESCUN MO, RIVAL C, THEAS MS, CALANDRA RS, LUSTIG L 2003: Involvement of tumor necrosisalpha in the pathogenesis of autoimmune orchitis in rats. Biol Reprod 68: 2114-2121

SUKHOTNIK I, VOSKOBOINIK K, LURIE M, CORAN AG, GREENBLATT R, SHILONI E, ELDAR S, MOGILNER JG 2007: Effect of testicular ischemia-reperfusion on recruitment of neutrophils, E-selectin expression and germ cell apoptosis in the contralateral testis in a rat. Pediatr Surg Int 5: 479-485

TEDDER TF, STEEBER DA, CHEN A, ENGEL P 1995: The selectins: vascular adhesion molecules. Faseb J 9: $866-873$ 
TURNER TT, TUNG KS, TOMOMASA H, WILSON LW 1997: Acute testicular ischemia results in germ cellspecific apoptosis in the rat. Biol Reprod 57: 1267-1274

WELLER A, ISENMAN S, VESTWEBER D 1992: Cloning of the mouse endothelial selectins. Expression of both E- and P-selectin is inducible by tumor necrosis factor alpha. J Biol Chem 267: 15176-15183 